\title{
Er kliniske etikk-komiteer i den kommunale helse- og omsorgstjenesten bærekraftige?
}

\author{
Lillian Lillemoen ${ }^{1}$, Irene Syse ${ }^{2}$, Reidar Pedersen ${ }^{3}$ og Reidun Forde ${ }^{4}$ \\ 1,2,3,4 Senter for medisinsk etikk, Institutt for helse og samfunn, Det medisinske \\ fakultet, UiO, lillian.lillemoen@medisin.uio.no
}

DOI: http://dx.doi.org/10.5324/eip.v10i2.1939

(cc) BY

This is an open access article distributed under the terms of the Creative Commons Attribution 4.0 International License, which permits unrestricted use, distribution, and reproduction in any medium, provided the original author and source are credited.

Kliniske etikkomiteer (KEK) har vort etablert i norske helseforetak siden 1996, først som et prøveprosjekt, senere som et permanent tiltak med et nasjonalt mandat. I forbindelse med det nasjonale etikkprosjektet «Samarbeid om etisk kompetanseheving» har det også $i$ noen kommuner blitt etablert KEK. Senter for medisinsk etikk ved Universitetet $i$ Oslo er tildelt ansvaret for oppfølging av KEK $i$ helseforetakene og er $i$ tillegg gitt et langsiktig ansvar for etikkarbeid og forskning $i$ den kommunale helse- og omsorgstjenesten. Hensikten med denne studien har voert å fremskaffe kunnskap om hvordan det står til med KEK som er etablert $i$ kommunene. Hva jobber de med, hvilken betydning erfarer de at KEK har og hvilke ressurser har de? Studien har et kvalitativt design. Materialet er basert på telefonintervjuer med ledere for KEK og gjennomgang av komiteenes årsrapporter. Det er gjennomført en kvalitativ innholdsanalyse av datamaterialet. Komiteene arbeider både med enkeltsaker, saker av mer prinsipiell karakter og etikkskolering. Arbeidet vurderes som betydningsfullt og gjennomføres til tross for få ressurser og svak forankring. Kanskje vil en styrket forankring og ressurssituasjon og et nasjonalt mandat bidra positivt til komiteenes arbeid.

Nøkkelord: Kliniske etikkomiteer, kommunal helse- og omsorgstjeneste, evaluering

English Summary: Are clinical ethics committees in the municipal health and care services sustainable?

Clinical ethics committees (CEC) have been established in Norwegian hospital trusts since 1996, first as a pilot project, later on a permanent basis with a national mandate. As part of the national ethics project "Cooperation on ethical competence" some municipalities have also established a CEC. Centre for Medical Ethics at the University of Oslo is given the responsibility to support CECs in hospital trusts, and is also given a long-term responsibility for ethics support and research in municipal health care services. The purpose of this study was to obtain knowledge about the situation of CECs established in municipalities. What are they working on, what impact do they find that CEC has, and what resources do they have? The study has a qualitative design. The material is based on telephone interviews with CEC chairs, and reviews of the committees' annual reports. We have carried out a qualitative content analysis of the data. The committees work with individual cases, issues of a 
more principle character, and ethics training. The work is considered to be significant, and is carried out despite limited resources and weak anchoring. Perhaps a stronger anchoring, resource situation and a national mandate could strengthen the committees' situation.

Keywords: Clinical ethics committees, municipal health and care services, evaluation

\section{Innledning}

"Helse- og omsorgsdepartementet, arbeidstakerorganisasjonene innen helse- og omsorg og kommunesektorens interesseorganisasjon (KS) etablerte i 2006 prosjektet «Samarbeid om etisk kompetanseheving». Prosjektet inviterte kommuner i hele landet til å delta i en nasjonal satsning for å styrke etikkompetansen hos ansatte i pleie- og omsorgssektoren. Satsningen i kommunene har for det meste vært opplæringstilbud i etikk for ansatte, skolering av ressurspersoner for kommunens etikkarbeid samt etablering av etikkrefleksjonsgrupper i pleie- og omsorgssektoren. Graden av forankring, systematikk og bærekraft i dette arbeidet har variert blant prosjektets deltakende kommuner (Gjerberg et al. 2014; Rapp Nilsen et al. 2015).

Noen få kommuner har i løpet av prosjektperioden etablert kliniske etikkomiteer/etikkråd. De fleste er etablert som etikkstøtte for kommunens helseog omsorgstjeneste, men noen har som formål å bistå samtlige av kommunens tjenesteområder. Senter for medisinsk etikk (SME) har lenge hatt nasjonalt ansvar for å bistå de kliniske etikkomiteene (KEK) i spesialisthelsetjenesten, og i forbindelse med prosjektet «Samarbeid om etisk kompetanseheving» er SME også gitt et langsiktig ansvar for å sikre oppbygging og forankring av etikkarbeidet i kommunene generelt og oppbygging av kliniske etikkomiteer i kommunene (KEKK) spesielt. Arbeidet med KEK i sykehusene har vist at jevnlig evaluering av arbeidet og de rammene komiteene arbeider under har vært viktig for kvaliteten på arbeidet (Førde, Pedersen \& Akre 2008; Pedersen, Akre \& Førde 2009; Kalager, Førde \& Pedersen 2011; Førde \& Pedersen 2011; Førde \& Pedersen 2012; Førde \& Ruud Hansen 2014). SME hadde på sin nettside, i november 2013, registrert elleve etikkomiteer i kommunene. Antall komiteer er siden da redusert og i september 2015 er det registrert ni etikkomiteer.

\section{Bakgrunn}

Kliniske etikkomiteer er en etablert tjeneste for etikkstøtte i helsetjenesten internasjonalt (McGee et al. 2001; Slowther, Hope, Ashcroft 2001). Stortinget besluttet i 2000 at alle helseforetak skal ha en klinisk etikkomite (Førde \& Thorleifsson 2003). I dag har disse etikkomiteene et nasjonalt mandat der det heter at komiteen skal sikres nødvendige ressurser og ha et eget budsjett, at leder og sekretær må sikres rammer som gjør det mulig å ivareta arbeidet innenfor vanlig arbeidstid ved frikjøp/fristilling fra annet arbeid, og at medlemmene må sikres rammer for å delta i arbeidet og kunne tilegne seg nødvendig kompetanse i klinisk etikk. 
Etikkomiteer har tradisjonelt flere oppgaver som alle går ut på å øke bevissthet rundt verdispørsmål i helsetjenesten. Én oppgave er å arrangere seminar for ansatte, en annen er å bidra i utarbeiding av etiske retningslinjer. Den kanskje viktigste oppgaven er å være beslutningsstøtte i etisk vanskelige veivalg. Det nasjonale mandatet har trolig bidratt positivt til komiteenes arbeid både ved å strukturere arbeidet og gi føringer for nødvendige ressurser for kvaliteten på arbeidet. Antall KEK har vokst gradvis. Mens det er gjennomført flere studier av kliniske etikkomiteer i helseforetakene (Førde \& Thorleifsson 2003; Pedersen \& Førde 2005; Førde \& Pedersen 2011; Kalager, Førde \& Pedersen 2011), har det til nå ikke vært gjennomført noen systematisk evaluering av komiteene i kommunene. Det må antas at arbeidet med å etablere godt fungerende etikkomiteer i kommunene er enda mer krevende enn i sykehusene. Kommunene er ulike og har ulik ressurssituasjon og geografi, sykehjemmene strever mange steder med mange ufaglærte, og mange ansatte arbeider alene med viktig ansvar for svake pasientgrupper som syke gamle og personer med psykiske og utviklingsmessige problemer. Det siste faktumet tilsier et stort behov for beslutningsstøtte og økt etisk bevissthet.

For å yte komiteene best mulig støtte er hensikten med denne studien å skaffe innsikt i komiteenes funksjon og betydning, inklusive hva slags saker/tema som har vært drøftet, samt hemmere og fremmere i komiteenes arbeid.

\section{Materiale og metode}

Data til denne studien er basert på telefonintervjuer med ti ledere av etikkomiteer i kommunene samt skriftlige årsrapporter fra seks komiteer.

\section{Telefonintervju}

Telefonintervjuene ble gjennomført høsten 2013 ved hjelp av en strukturert intervjuguide. Spørsmålene, totalt 31, dreide seg om komiteens sammensetning og kompetanse, organisatorisk forankring og økonomisk situasjon og hvilken betydning lederne erfarte at komiteens arbeid har hatt. Invitasjon til å delta i intervjuet samt intervjuguide ble sendt pr. e-post til alle registrerte komiteledere forut for intervjuene. Av elleve inviterte, takket ti ja til å delta. Under intervjuene ble det ikke benyttet opptaksutstyr, men svarene på spørsmålene ble fortløpende notert ned. Intervjuene varte fra 40 til 60 minutter. For å sikre utfyllende nedtegninger, ble notatene fra intervjuene skrevet ut $\mathrm{i}$ sin helhet umiddelbart etter at de var gjennomført.

\section{Årsrapporter}

For å skaffe dypere innsikt i hvilke spørsmål KEKK har arbeidet med har det vært nødvendig å studere årsrapportene som er sendt SME. Innsendte årsrapporter fra etikkomiteene for 2011-2014, totalt 12, er en del av studiens datagrunnlag. Disse legges på SMEs nettside. http://www.med.uio.no/helsam/tjenester/kunnskap/etikkhelsetjenesten/kommunehelsetjenesten/komiteer/

Ikke alle komiteene er registrert med årsrapporter, og utvalget av årsrapporter til denne studien begrenser seg derfor til de seks som har sendt inn årsrapporter (se tabell 1). Rapportene er gjennomlest med spesielt fokus på komiteenes virksomhet: 
hvilke saker som har vært drøftet, hvilke konklusjoner og eventuell råd komiteene har gitt, samt hvilke andre aktiviteter komiteene har arbeidet med.

Tabell 1: Registrerte etikkomiteer pr. nov. 2013 med innsendte årsrapporter pr. sept. 2015

\begin{tabular}{|l|c|c|c|c|}
\hline & 2011 & 2012 & 2013 & 2014 \\
\hline Etikkomite A & $\mathrm{X}$ & $\mathrm{X}$ & $\mathrm{X}$ & $\mathrm{X}$ \\
\hline Etikkomite B & $\mathrm{X}$ & & & $\mathrm{X}$ \\
\hline Etikkomite C & & $\mathrm{X}$ & $\mathrm{X}$ & \\
\hline Etikkomite D & & & $\mathrm{X}$ & $\mathrm{X}$ \\
\hline Etikkomite E & & & & \\
\hline Etikkomite F & & & & \\
\hline Etikkomite G & & & & \\
\hline Etikkomite H & & & & \\
\hline Etikkomite I & & & & \\
\hline Etikkomite J & & & & \\
\hline Etikkomite K & & & & \\
\hline
\end{tabular}

\section{Analyse}

Det er gjennomført en deskriptiv analyse av studiens tekstmateriale, som består av transkriberte intervjuer og tolv årsrapporter. Tekstene er lest gjentatte ganger av forskerne hver for seg, og senere diskutert i fellesskap. Analysearbeidet har, med studiens forskningsspørsmål som utgangspunkt, resultert i følgende tre grupperinger av funn: KEKK-enes aktivitet; Betydningen; Sammensetning og rammer. Den første hovedgruppen, KEKK-enes aktivitet, er presentert ved hjelp av tre undergrupper av funn: Enkeltsaker; Prinsipielle saker; Undervisning og veiledning.

\section{Forskningsetiske vurderinger}

Studien inneholder ikke personidentifiserende informasjon og det er ikke lagret lydfiler fra intervjuene, noe som gjør at studien ikke er registreringspliktig hos Norsk samfunnsvitenskapelig datatjeneste (NSD). Samtlige deltakere ble på forhånd informert om studiens hensikt og innhold, og deltakelse i studien er basert på et informert samtykke. Data er anonymisert slik at ledere, komitemedlemmer og/eller saker drøftet i komiteene ikke er identifiserbare.

\section{Resultater}

\section{KEKK-enes aktivitet}

Det var en samlet oppfatning blant lederne at komiteene gjerne skulle sett at de fikk flere henvendelser. Mens for eksempel én komite hadde blitt bedt om hjelp til å 
drøfte syv saker i løpet av det siste året, hadde de andre hatt mellom én og tre saker til drøfting i den samme perioden. Noen av lederne trakk fram at de som en del av virksomheten sin hadde utdannet lokale eller avdelingsvise etikkveiledere. Etikkveilederne bidro igjen til at de ansatte var blitt bedre til å håndtere etiske problemer lokalt på sine arbeidsplasser, noe lederne mente kunne være en forklaring på at komiteen fikk færre henvendelser.

Samtlige komiteer benytter SME-modellen (se boks 1) som struktur når de drøfter de konkrete pasientsakene (Ruyter, Førde, Solbakk 2014). Modellen blir erfart som god, dels på grunn av dens tydelige struktur, dels fordi strukturen utfordrer dem til å utforske ikke bare fakta i saken, men også berørte parters syn på saken og mulige handlingsalternativer. I noen komiteer er det vanlig praksis at sakseier inviteres til å delta i drøftingen, og noen har også gjennomført drøftinger hvor pårørende har deltatt.

Boks 1: Modell for systematisk drofting av etiske dilemma [SME-modellen]

- Hva er de(t) etiske dilemma(et) i denne saken?

- Hva er fakta i saken (medisinske og psykososiale)?

- Hvem er de berørte partene i saken, og hva er deres syn og interesser i saken?

- Hvilke etiske prinsipper, dyder og verdier står på spill, og hva finnes av relevant lovgivning og etiske retningslinjer?

- Hvilke handlingsalternativ finnes, og hvilke begrunnelser har disse?

- Hvilken løsning er eventuelt den foretrukne?

\section{Enkeltsaker}

Enkeltsaker som har vært drøftet i komiteene er her organisert i fire hovedtema: a) Livsforlengende behandling; b) Uenighet mellom pårørende og helsepersonell; c) Autonomi vs. tvang; d) Prioriteringsspørsmål. Tabell 2 viser at sakene ofte var kompliserte og inneholdt flere etiske dilemma, for eksempel både dilemma knyttet til behandlingsbegrensning og uenighet om pårørende som beslutningstakere.

\section{Prinsipielle saker og retningslinjer}

I tillegg til etiske problemer knyttet til enkeltsaker, hadde flere av komiteene drøftet saker av mer prinsipiell karakter, som for eksempel: Hvilken informasjon er det forsvarlig og nødvendig at samarbeidende helsepersonell får om pasienter med psykisk sykdom som tilbakeføres til kommunen etter å ha sonet voldsdom i psykiatrisk institusjon? Noen av komiteene hadde også arbeidet med å utvikle retningslinjer for deler av tjenesten, som for eksempel: Hvordan skal en på best mulig måte, med respekt for den avdøde og de øvrige beboerne, forflytte avdøde beboere ut fra avdelingen? En komite hadde bistått kommuneledelsen med en konkretisering av begrepene «faglig forsvarlig» og «omsorgsfull hjelp». 
Tabell 2: Eksempler på saker som har vært droftet ${ }^{1}$

\begin{tabular}{|c|c|c|c|}
\hline $\begin{array}{l}\text { Livsforlengende } \\
\text { behandling }\end{array}$ & $\begin{array}{l}\text { Uenighet mellom } \\
\text { pårørende og } \\
\text { helsepersonell }\end{array}$ & Autonomi vs. tvang & $\begin{array}{l}\text { Prioriterings- } \\
\text { spørsmål }\end{array}$ \\
\hline $\begin{array}{l}\text { Uenighet mellom } \\
\text { lege og pårørende } \\
\text { om opprettholdelse } \\
\text { av livsforlengende } \\
\text { behandling/sonde- } \\
\text { ernæring til yngre } \\
\text { pasient med } \\
\text { neurologisk lidelse } \\
\text { og demens. Stor } \\
\text { uenighet mellom } \\
\text { lege, pleiepersonalet } \\
\text { og pårørende om: } \\
\text { «Hva er et verdig } \\
\text { liv?» } \\
\text { KEKK anbefaler at } \\
\text { det gjøres en ny } \\
\text { medisinsk vurdering } \\
\text { av pasienten, av } \\
\text { sykdomsutviklingen } \\
\text { og muligheten for } \\
\text { bedring. KEKK } \\
\text { anbefaler også et det } \\
\text { gjennomføres et } \\
\text { avklarende møte } \\
\text { mellom lege og } \\
\text { pårørende, samt at } \\
\text { man er tydeligere i } \\
\text { sin kommunikasjon } \\
\text { - at det legges vekt } \\
\text { på at lindrende } \\
\text { behandling også er } \\
\text { behandling. }\end{array}$ & $\begin{array}{l}\text { Yngre pasient med } \\
\text { hemiparese etter } \\
\text { cerebralt insult og } \\
\text { multiinfarkt- } \\
\text { demens. Akutt } \\
\text { sykehus-innlagt pga. } \\
\text { fall, ingen brudd. Av } \\
\text { sykehuslege besluttet } \\
\text { HLR minus. } \\
\text { Pårørende } \\
\text { informerte at de og } \\
\text { pasienten motsetter } \\
\text { seg dette. } \\
\text { Sykehjemslege vil } \\
\text { ikke endre vedtaket. } \\
\\
\text { Drøftingen resulterte } \\
\text { i en uttalelse fra } \\
\text { KEKK om at det er } \\
\text { helsepersonell som } \\
\text { har ansvar for å } \\
\text { beslutte om HLR er } \\
\text { nytteløs medisinsk } \\
\text { behandling eller } \\
\text { ikke. KEKK påpeker } \\
\text { at tillitsskapende } \\
\text { arbeid er viktig, og at } \\
\text { pasientens } \\
\text { preferanser trekkes } \\
\text { inn når beslutning } \\
\text { skal gjøres. KEKK } \\
\text { anbefaler ny } \\
\text { vurdering av pasient } \\
\text { og at pasientens } \\
ø n s k e \text { om å leve / } \\
\text { livsglede bør } \\
\text { vektlegges. Det pekes } \\
\text { også på muligheten } \\
\text { for å søke second } \\
\text { opinion, samt } \\
\text { viktigheten av at det } \\
\text { informeres om } \\
\text { pårørendes rett til å } \\
\text { klage til Fylkeslege/ } \\
\text { Helsetilsyn. }\end{array}$ & $\begin{array}{l}\text { Pasient som } \\
\text { motsatte seg } \\
\text { nødvendig } \\
\text { behandling. Fordi } \\
\text { det er vanskelig å } \\
\text { vurdere pasientens } \\
\text { samtykkekompetans } \\
\text { e er ansatte som } \\
\text { henvender seg } \\
\text { KEKK usikre på hva } \\
\text { de skal gjøre. } \\
\text { Drøftingen i } \\
\text { komiteen ender med } \\
\text { at KEKK anbefaler et } \\
\text { nytt møte mellom } \\
\text { berørte parter for å } \\
\text { sjekke ut om all } \\
\text { informasjon er } \\
\text { forstått. }\end{array}$ & $\begin{array}{l}\text { Spørsmålet som } \\
\text { bringes inn for } \\
\text { KEKK er hvor lenge } \\
\text { en pasient skal få } \\
\text { rehabiliterings- } \\
\text { opphold. Den } \\
\text { aktuelle pasienten } \\
\text { aksepterer bare deler } \\
\text { av opplegget, men } \\
\text { nekter også } \\
\text { hjemreise. } \\
\text { KEKK anbefaler at } \\
\text { man er tydelig og } \\
\text { konkret i } \\
\text { kommunikasjonen. } \\
\text { Videre anbefaler } \\
\text { KEKK at det } \\
\text { gjennomføres et } \\
\text { nettverksmøte der } \\
\text { man bl.a. legger vekt } \\
\text { på å avklare hva som } \\
\text { er pasientens } \\
\text { forventninger, at det } \\
\text { utarbeides en } \\
\text { rehabiliteringsplan } \\
\text { og at det legges en } \\
\text { god plan som } \\
\text { forbereder } \\
\text { pasientens } \\
\text { hjemreise. }\end{array}$ \\
\hline
\end{tabular}




\begin{tabular}{|c|c|c|c|}
\hline $\begin{array}{l}\text { Helsepersonellet er i } \\
\text { tvil om man skal } \\
\text { fortsette å behandle } \\
\text { en ung, vegetativ } \\
\text { pasient med stadig } \\
\text { tilbakevendende } \\
\text { lungebetennelser. }\end{array}$ & $\begin{array}{l}\text { Uenighet mellom } \\
\text { pårørende og } \\
\text { sykehuslege om } \\
\text { reinnleggelse av } \\
\text { PEG-sonde til en } \\
\text { yngre pasient med } \\
\text { demens etter at han } \\
\text { gjentatte ganger har } \\
\text { dratt ut sonden selv. } \\
\text { KEKK anbefaler at } \\
\text { pårørende snakker } \\
\text { med pasienten } \\
\text { sammen med en } \\
\text { pleier som kjenner } \\
\text { pasienten godt og } \\
\text { prøver å få vite noe } \\
\text { om pasientens } \\
\text { opplevelse av smerte, } \\
\text { syn på sonde og } \\
\text { videre behandling. } \\
\text { Møte mellom } \\
\text { pårørende og } \\
\text { personalet for å ta } \\
\text { opp ting pårørende } \\
\text { opplever } \\
\text { utilfredsstillende. } \\
\text { Institusjonssjef søker } \\
\text { om økt bemanning } \\
\text { (1:1). }\end{array}$ & $\begin{array}{l}\text { Pasient som } \\
\text { motsatte seg } \\
\text { nødvendig } \\
\text { medisinsk } \\
\text { behandling: } \\
\text { Pasienten er vurdert } \\
\text { samtykkekompetent. } \\
\text { Lege og øvrig } \\
\text { personale er } \\
\text { innbyrdes uenige. } \\
\text { Pasienten er vurdert } \\
\text { samtykkekompetent, } \\
\text { og komiteens } \\
\text { vurdering er da at } \\
\text { behandlere må } \\
\text { forholde seg til } \\
\text { pasientens } \\
\text { beslutning, selv om } \\
\text { legens medisinske } \\
\text { vurdering ikke } \\
\text { samsvarer med } \\
\text { pasientens } \\
\text { beslutning. }\end{array}$ & $\begin{array}{l}\text { Sterke fronter } \\
\text { mellom ansatte på } \\
\text { sykehjem og } \\
\text { rehabiliteringssenter. } \\
\text { Saken dreier seg om } \\
\text { senterets strenge } \\
\text { krav om at pasienter } \\
\text { skal være motivert - } \\
\text { et krav som viser seg } \\
\text { vanskelig å innfri for } \\
\text { pasienter med } \\
\text { kognitiv svikt. } \\
\text { KEKK inviterte } \\
\text { partene fra senteret } \\
\text { og sykehjemmet til } \\
\text { drøftingen, og } \\
\text { resultatet ble positivt } \\
\text { i form av at de fikk } \\
\text { større forståelse for } \\
\text { hverandres } \\
\text { synspunkter og } \\
\text { vurderinger. }\end{array}$ \\
\hline & $\begin{array}{l}\text { Uenighet mellom } \\
\text { personalet og } \\
\text { pårørende om å } \\
\text { avslutte aktiv } \\
\text { medisinsk, og } \\
\text { overgang til palliativ } \\
\text { behandling - } \\
\text { kulturelle forhold av } \\
\text { betydning for saken. } \\
\text { KEKK innhentet } \\
\text { info om } \\
\text { kulturelle/religiøse } \\
\text { forhold - f.eks. at } \\
\text { mennesker ikke kan } \\
\text { avslutte behandling } \\
\text { når den er iverksatt. } \\
\text { KEKK konkluderer } \\
\text { med at drøftingen } \\
\text { resulterte i en økt }\end{array}$ & $\begin{array}{l}\text { Saken dreier seg om } \\
\text { ansattes mistanke } \\
\text { om tvangsmating og } \\
\text { bruk av makt fra et } \\
\text { familiemedlem som } \\
\text { er på jevnlig besøk } \\
\text { hos en pasient som } \\
\text { bor i en institusjon. } \\
\text { Drøftingen avdekket } \\
\text { at det manglet } \\
\text { sentral informasjon } \\
\text { om fakta i saken. } \\
\text { KEKK anbefaler at } \\
\text { dersom det brukes } \\
\text { makt i mating av } \\
\text { pasienten må ansatte } \\
\text { ta ansvaret for at det } \\
\text { opphører. Leder bør } \\
\text { invitere til møter i }\end{array}$ & \\
\hline
\end{tabular}




\begin{tabular}{|l|l|l|l|}
\hline & forståelse fra & den hensikt å gi \\
personalgruppen & informasjon. Støtte \\
mht. kulturelle og & religiøse forhold i \\
saken. & $\begin{array}{l}\text { og helpe både } \\
\text { pårørende og } \\
\text { ansatte. }\end{array}$ & \\
\hline
\end{tabular}

\section{Undervisning og veiledning}

I tillegg til å drøfte henvendelser, har noen få komiteer bidratt med kompetansehevende tiltak i etikk, både teoriformidling og trening i å lede etikkrefleksjon for ansatte, ledere i kommunens helse- og omsorgstjeneste og etikkveiledere for refleksjonsgrupper. Eksempel på tema er tvang og tvangsproblematikk, etiske dilemma ved livets slutt og behandlingsavklaring og forberedende samtaler. Skoleringen varierer i omfang, fra dagskurs, til månedlige halvdags kurs over et semester. Flere komiteer har også etablert et nettverk for kommunens ressurspersoner i etikkarbeidet (etikkveilederne/etikkontaktene). Nettverksmøtene brukes til erfaringsdeling og gjennomføres alt fra en gang i halvåret til en gang pr. måned.

Mange komiteledere sa eksplisitt at de så behovet for etikkurs for ansatte i egen kommune og at de gjerne skulle bidratt til at etikkompetansen i kommunen ble utviklet, både blant ledere, ansatte og komitemedlemmer. På grunn av få ressurser så de imidlertid ikke noen mulighet for å gjennomføre det. Også de lederne som gjennomførte utadrettet virksomhet påpekte at de drev en «skjør» virksomhet, både på grunn av små økonomiske ressurser og på grunn av begrenset kompetanse innad i etikkomiteen.

\section{Betydningen}

Et av de gjennomgående svarene fra komitelederne var at etikkomiteen satte etikk ordentlig på dagsorden. Komiteenes årsrapporter understøtter dette inntrykket. Etiske problemer og håndteringen av dem var i følge lederne ikke lenger bare den enkeltes ansvar; nå snakket man mer sammen om de etisk vanskelige situasjonene, og etikkarbeid ble sett på som noe positivt.

Alvoret og kompleksiteten i spørsmålene som komiteene har arbeidet med (se tabell 2) indikerer at det er behov for tid, rom og kompetanse til å drøfte denne type saker, både i egne fora og ute i avdelingene / de kommunale tjenestene. Gjennom etablering av en etikkomite hadde man skapt et nytt strukturelt grep i kommunen, et grep som innebar at man erkjente at etiske problemer var en del av tjenesteutøvelsen og at helsepersonell trengte støtte for å håndtere problemene på en god måte. De aller fleste lederne mente at etikkomiteenes arbeid hadde hatt en positiv betydning for tjenestene.

\section{Sammensetning og rammer}

Komitemedlemmene var stort sett helsepersonell: sykepleiere, vernepleiere og hjelpepleiere. Mange, men ikke alle, hadde lege. Flere av komiteene hadde også legmann, og noen få hadde jurist. Et lite mindretall hadde et eksternt medlem med etikkompetanse i komiteen. Noen få av lederne oppga medlemmenes frammøte som utilfredsstillende. En av disse sa eksplisitt at det var vanskelig å få leger og 
hjelpepleiere som deltar i pasientpleie/-behandling til å møte. Noen hadde løst dette med rekruttering av medlemmer som ikke deltok i direkte pasientpleie/-behandling. Andre hadde redusert oppmøteproblemene med å utarbeide møteplaner slik at medlemmene kunne planlegge komitemøtene frem i tid.

Tilstrekkelig tid til å lede komiteen var viktig for komiteenes arbeid. Kun én av lederne oppga å være frikjøpt i $20 \%$ fra sitt ordinære arbeid. Over halvparten av de som ikke hadde frikjøpt tid til komitearbeidet mente likevel at de klarte å ivareta funksjonen som komiteleder, siden deres ordinære stilling var preget av en viss fleksibilitet og at de selv kunne påvirke egne arbeidsoppgaver. Komitelederne som ikke hadde denne muligheten til fleksibilitet strevde med å få tid til komitearbeidet. Sekretærfunksjonen var løst ulikt i komiteene. I to komiteer ivaretok lederen også sekretærfunksjonen, i en annen lot man den gå på omgang blant medlemmene. De resterende syv komiteene hadde egne sekretærer, flesteparten helsepersonell uten spesifikk kompetanse til funksjonen og ingen av dem med frikjøpt tid til arbeidet.

Syv komiteer hadde eget budsjett som varierte fra kr 20000 til kr 43000 per år. Selv om flesteparten fikk tildelte midler fra kommunen, hadde noen søkt og fått tildelt eksterne midler. De tre komiteene som ikke hadde eget budsjett, belastet det enkelte komitemedlemmets avdeling for utgifter, for eksempel kurs- og reiseutgifter. Noen oppgav at de, ved opptak av nye komitemedlemmer, satte som forutsetning at medlemmets arbeidssted samtykket i å påta seg utgifter knyttet til komitearbeid. Dette gjaldt ikke bare dekking av kurs- og reiseutgifter, men også utgifter til å leie inn vikar.

De fleste lederne mente at budsjettet ikke var tilstrekkelig til at de kunne drive komitearbeidet slik de ønsket og mente at det var behov for, for eksempel, muligheter både for å sende medlemmene på kurs og for å videreutvikle etikkarbeidet i kommunene.

$\mathrm{Ni}$ av lederne mente at etikkomiteen var forankret i kommunen, men det var varierende oppfatning av på hvilket nivå arbeidet var forankret, og forankringens substans og verdi. En av lederne beskrev komiteens forankring slik:

«Vi er forankret på rådmannsnivå, men uten medfølgende budsjett».

En annen oppga at komitearbeidet var forankret i samtlige av kommunens plandokumenter og at kommunens ledere derfor ble målt direkte på hvordan og $\mathrm{i}$ hvilken grad etikkarbeidet ble gjennomført innenfor deres virksomhet. Andre sa at det var KS-prosjektet «Samarbeid om etisk kompetanseutvikling» som var forankret, og at de var usikre på om etikkomiteen som et særskilt tiltak var forankret noe sted. En komiteleder sa eksplisitt at etikkomiteen ikke hadde noen form for godkjenning fra kommunens ledelse. Begrunnelsen for likevel å opprettholde aktiviteten i etikkomiteen var komiteleder og komitemedlemmenes antakelse om at det var mange som ønsket at arbeidet skulle videreføres. Halvparten av komitelederne var usikre på om komitearbeidet var forankret hos de ansatte.

De fleste oppgav at de skrev referat, men at de ikke refererte på en systematisk måte de sakene som hadde vært drøftet i komiteen.

\section{Diskusjon}

Drøftingen av funn skjer med studiens forskningsspørsmål som utgangspunkt. Studiens funn er abstrahert til et begrepspar som synes å være betegnende for 
situasjonen i de kliniske etikkomiteene i kommunene: «Betydningsfull men skjør virksomhet». Vi vil i fortsettelsen drøfte studiens funn strukturert etter begrepsparet.

\section{Betydningsfull men skjor virksomhet Betydningsfull virksomhet}

Resultatene viser at etikkomiteenes arbeid oppleves å ha en positiv betydning for tjenestene de representerer; det er blitt mer legitimt å snakke om etiske problemer, og etiske problemer er ikke lenger bare et privat anliggende. Dette er ikke overraskende resultater, også annen forskning viser at tilrettelegging av arenaer for systematisk refleksjon og drøfting av etiske problemer har en positiv betydning både når det gjelder oppmerksomheten på etikk og på håndteringen av etisk utfordrende situasjoner (Söderhamn et al. 2015; Lillemoen \& Pedersen 2015). Arenaer for systematisk drøfting av etiske problemer, som for eksempel etikkrefleksjonsgrupper og kliniske etikkomiteer, er to viktige måter å gjøre etikken allmenn og systematisk, samt å møte helse- og omsorgstjenestens behov for etisk refleksjon og drøfting.

Etablering av etikkrefleksjonsgrupper er det etikktiltaket som flest kommuner har valgt å satse på i det nasjonale etikkprosjektet (Boge 2010; Gjerberg et al. 2014). Dette er et tiltak som i stor grad vurderes å ha en positiv betydning for helsepersonell og for tjenesten de utøver (Gjerberg et al. 2014; Söderhamn et al. 2015; Lillemoen \& Pedersen 2015). Dette synes å være et godt tiltak som både hjelper helsepersonellet til ny forståelse, handlingsalternativer og styrker deres evne til samarbeid (Lillemoen \& Pedersen 2015).

Den kommunale helse- og omsorgstjenesten, og særlig sykehjemstjenesten, omtales hyppig som en tjeneste med mange ufaglærte og ansatte med lav kompetanse (Kompetanseløftet 2015). Mangelfull involvering av pasienter og pårørende gjør også at tjenesten risikerer en uheldig slagside, der alvorlige beslutninger med store konsekvenser fattes på et mangelfullt faglig grunnlag. I tillegg preges deler av den kommunale helse- og omsorgstjenesten av stor grad av alenejobbing, og kompliserte etiske situasjoner må ofte håndteres alene. Riksrevisjonens undersøkelse av ressursutnyttelse og kvalitet i helsetjenesten etter innføringen av samhandlingsreformen viser blant annet at det overføres og behandles et langt større antall sårbare og multi-syke pasienter i kommunehelsetjenesten uten at kompetansen er økt tilsvarende (Dokument 3:5 (2015-2016)). Våre funn viser at mange av de etiske problemene som er drøftet i etikkomiteene dreier seg om livets slutt, situasjoner som er av stor betydning for de etterlatte. Betydningen av kompetanse og etisk bevissthet er derfor åpenbar. Kanskje bidrar etikkomiteene til å få beslutningsprosesser som har gått i lås inn på et fruktbart spor. Vi har grunn til å tro at dersom konflikter løses på en god måte og på et riktig tidspunkt gjennom etikkveiledning, så vil dette være energi- og økonomisk besparende (Schneiderman et al. 2003). At etiske problemstillinger tas på alvor og at berørte parter inviteres til en åpen og inkluderende dialog er med på å styrke tilliten til helsevesenet.

Når noe defineres som et etisk problem og drøftes systematisk, bidrar det til at en setter ord på områder som ofte har et forbedringspotensial. I tillegg til enkeltsaker og saker av mer prinsipiell karakter, var det også komiteer som hadde arbeidet med utvikling av retningslinjer og kompetanseheving tilpasset tjenestenes 
behov. Dette må kunne karakteriseres som et viktig kvalitetsutviklingsarbeid, og ikke minst av den grunn burde etikkomiteene vekke ledernes interesse.

\section{Skjorhet}

Til tross for at virksomheten til etikkomiteene vurderes å være av stor betydning, viser undersøkelsen at komiteene gis en lav prioritet fra kommunenes administrasjon. Svak forankring og liten støtte fra ledelsen resulterer i at en stor del av ansvaret for komiteens virksomhet hviler på komitelederen. Undersøkelsen viser at komitearbeidet $\mathrm{i}$ stor grad er avhengig av engasjerte ressurspersoner. Framfor noen gjelder dette komitelederne som pålegger seg selv et ofte uskrevet ansvar for at komiteen skal bestå. Dagens situasjon for etikkomiteene i den kommunale helse- og omsorgstjeneste er skjør. Det virker som om det framfor alt er komiteledernes og medlemmenes opplevelse av arbeidet som betydningsfullt for tjenestene som gjør at virksomheten opprettholdes. Hadde komitelederne hatt kliniske stillinger og arbeidet turnus, og ikke som nå en stilling med mulighet til å påvirke og planlegge egen arbeidshverdag, ville det trolig vært langt vanskeligere å opprettholde komitearbeidet. Dette er imidlertid ikke enestående for etikkomiteene, og selv om etikkrefleksjonsgrupper kanskje har en sterkere forankring, opplever også etikkveiledere for disse gruppene seg som «ildsjeler». Etikkarbeidet synes å være avhengig av ildsjeler, enten det skjer i refleksjonsgrupper eller i komiteer, og behovet for støtte og oppfølging synes framtredende (Gjerberg et al. 2014; Tønnessen et al. 2016).

Et av kravene til kommunene i det nasjonale etikkprosjektet var etablering av møteplasser for etisk refleksjon, et tiltak som skulle være forankret i kommunens ledelse. Tidlig og ny evaluering av etikkprosjektet viser at grad av forankring varierer, men på et generelt grunnlag må man kunne beskrive den som svakere enn ønsket (Gjerberg et al. 2014; Rapp Nilsen et al. 2015). I de senere år av det nasjonale etikkprosjektet kan det se ut til at etikkrefleksjonsgrupper har fătt en sterkere forankring, noe som er en kontrast til det lederne for etikkomiteene erfarer. Hvordan kan man forklare komiteenes svake forankring i kommunenes administrasjoner? Kan forklaringen være at dette er et arbeid man vurderer å være av liten eller ingen betydning for praksis? Eller kan det tenkes at administrasjonen sitter for langt fra praksisfeltet, og at kontakten med tjenestene er for liten til at de blir oppmerksom på betydningen av komitearbeidet? Kanskje dreier etikkarbeid generelt, og komitearbeid spesielt, seg om et nybrottsarbeid som få ledere kan noe om og hvor en generelt har lite erfaring og kunnskap. Etter vår vurdering representerer de kliniske etikkomiteene en ny mulighet for den kommunale helseog omsorgssektorens administrative og politiske ledelse til kvalitetsarbeid i praksis, og kanskje vil nettopp etablering av etikkrefleksjonsgrupper og etikkomite i en og samme kommune bidra til sterkere strukturer i det systematiske etikkarbeidet.

Etiske problemstillinger er komplekse og preget av faglige, etiske og juridiske implikasjoner, og krever derfor bredt sammensatte komiteer. Like viktig er det at også medlemmer fra klinisk arbeid, som møter pasienter og pårørende, inngår. Undersøkelsen viser at selv om de fleste komiteene har bestrebet seg på en tverrfaglig sammensetning, er hovedvekten av komitemedlemmene fra pleiesektoren. Lav deltakelse fra andre faggrupper, som for eksempel fysioterapeuter, leger og sosionomer, svekker ikke bare komiteens intensjon om å være et tverrfaglig forum for etisk drøfting, men også det mangfold av gode faglige 
og etiske argumenter som en tverrfaglig sammensetning ville bidratt til. Også skjevhet i komiteens sammensetning, med for eksempel overvekt av administrativt ansatte, vil kunne føre til for stor distanse til problemstillingene og for dårlig kompetanse i drøftingen.

Undersøkelsen viser at majoriteten av komiteene benytter SME-modellen som struktur for drøfting av de konkrete enkeltsakene, mens det til dels er store variasjoner i hvordan drøftingene blir dokumentert. Dette er til forveksling likt det man fant i en undersøkelse av de kliniske etikkomiteene i spesialisthelsetjenesten før det nasjonale mandatet (Førde \& Pedersen 2011). Vi har grunn til å anta at et nasjonalt mandat, i likhet med det som etikkomiteene i spesialisthelsetjenestene har, vil bidra positivt både til forankring, økonomi, saksbehandling og dokumentasjon. En utfordring med et slikt mandat er om det er mest hensiktsmessig med en komite per kommune, felles komiteer for flere kommuner eller felles for kommuner og helseforetak. Dette er noe som bør undersøkes nærmere, f.eks. ved å prøve ut og evaluere ulike måter å organisere komiteene på.

Svak økonomi gjør det vanskelig å profilere etikkomiteen og informere om hva den kan brukes til. Manglende profilering er trolig en medvirkende forklaring til at mange komiteer opplever at de får relativt få henvendelser. En annen forklaring er at mange helsearbeidere i den kommunale helse- og omsorgstjeneste er så vant til å jobbe alene og finne løsninger på egen hånd, at de ikke tenker på etikkomiteen som et alternativ. Etablering av nye arenaer for kvalitetsarbeid som dette vil kreve tid og tålmodighet.

\section{Konklusjon}

Etikkomiteene i den kommunale helse- og omsorgstjenesten bidrar med viktige innspill til håndteringen av vanskelige og komplekse spørsmål. Det er imidlertid få slike komiteer i Norge per i dag, og de preges av svak forankring i kommunenes administrative ledelse. Sterke ressurspersoner som erfarer komitearbeidet som betydningsfullt for tjenestene, er de som til tross for små ressurser opprettholder denne formen for lokalt kvalitets- og kompetanseutviklingsarbeid.

Gitt at etikkomiteer er et godt tiltak i et systematisk etikkarbeid, ikke bare i spesialist- men også i kommunehelsetjenesten, da er styrking av rammene for komitearbeidet nødvendig. Undersøkelsen viser at forankringen av kliniske etikkomiteer, både blant de ansatte, hos lokale ledere og hos ledelsen på kommunalt nivå, har et betydelig potensial for forbedring. Mens etikkomiteene i spesialisthelsetjenestene har et nasjonalt mandat, er dette ikke tilfellet for komiteene i den kommunale helse- og omsorgstjenesten. Kanskje vil et slikt mandat bidra til å styrke det viktige arbeidet komiteene gjør.

\section{Noter}

${ }^{1}$ Årsrapportene viste variasjon mht. dokumentasjon av drøftingens evt. konklusjon. 


\section{Referanser}

Boge R. Evaluering av prosjekt; samarbeid om etisk kompetanseheving. Senter for omsorgsforskning $i$ Vest. Hovedrapport mai 2010. http://www.hib.no/senter/ omsorgsforskning/prosjekter/EtiskKompetansehevingSluttrapp ort.pdf

Førde R, Thorleifsson E. Klinisk etikkomite ved sjukehus - et nyttig forum eller fremmed fugl? Tidsskrift for den norske legeforening. 2003; 18 (123): 2603-5

Førde R, Pedersen R, Akre V. Clinicians' evaluation of clinical ethics consultations in Norway: a qualitative study. Medicine, Health Care and Philosophy. 2008; 11(1):17-25. http://dx.doi.org/10.1007/s11019-007-9102-2

Førde R, Pedersen R. Clinical ethics committees in Norway: What do they do, and does it make a difference? Cambridge Quarterly of Healthcare Ethics. 2011; 20: 389-395. http://dx.doi.org/10.1017/S0963180111000077

Førde R, Pedersen R. Evaluation of case consultations in clinical ethics committees. Clinical Ethics. 2012; 7:45-50. http://dx.doi.org/10.1258/ce.2012.012m03

Førde R, Ruud Hansen TW. Do organizational and clinical ethics in hospital setting need different venues? HEC Forum. 2014; 26 (2):147-158. http://dx.doi.org/10.1007/s10730-014-9237-5

Gjerberg, E., Lillemoen, L., Dreyer, A., Pedersen, R., \& Førde, R. (2014). Etisk kompetanseheving i norske kommuner - hva er gjort, og hva har vært levedyktig over tid?. Etikk i Praksis - Nordic Journal of Applied Ethics, 8(2), 3149. http://dx.doi.org/10.5324/eip.v8i2.1855

Helse- og omsorgsdepartementet. Omsorgsplan 2015. Særtrykk av St.prp.nr. 1 (2007-2008).

Kalager G, Førde R, Pedersen R. Er drøfting av pasientsaker i klinisk etikk-komiteer nyttig? Tidsskrift for den norske legeforening.2011; 213 (1): 118-21

Lillemoen L, Pedersen R. Ethical challenges and how to develop ethics support in primary health care. Nursing Ethics. 2013; 20 (1): 96108. http://dx.doi.org/10.1177/0969733012452687

Lillemoen L, Pedersen R. Ethics reflection groups in community health services: an evaluation study. BMC Medical Ethics. 2015; 16 (25). http://dx.doi.org/10.1186/s12910-015-0017-9

McGee G, Spanogle JP, Caplan AL, Ash DA. A national study of ethics committees. The American Journal of Bioethics. 2001; 1 (4): 60-64. http://dx.doi.org/10.1162/152651601317139531

Nasjonalt mandat for kliniske etikk-komiteer i spesialisthelsetjenesten: http://www.siv.no/SiteCollectionDocuments/Fagfolk/Klinisk\%20etikkomite/Nas jonalt_mandat_KEK2011.pdf

Pedersen R, Førde R. Hva gjør de kliniske etikkomiteene? Tidsskrift for den norske legeforening. 2005; 22 (125): 3127-9

Pedersen R, Akre V, Førde R. Barriers and challenges in clinical ethics consultations: The experience of nine clinical ethics committees. Bioethics. 2009; 23 (8):460-469. http://dx.doi.org/10.1111/j.1467-8519.2008.00664.x

Pedersen R, Akre V, Førde R. What is happening during case deliberations in clinical ethics committees? A pilot study. Journal of Medical Ethics. 2009; 35 (3):147-152. http://dx.doi.org/10.1136/jme.2008.026393

Rapp Nilsen H, Antonsen Y, Nordmann AK, Kirkhaug R, Tønnessen S. Evaluering av det nasjonale prosjektet "Samarbeid om etisk kompetanseheving". Styring ledelse og gjennomføring. NORUT rapport 12/2015 
Riksrevisjonens undersøkelse av ressursutnyttelse og kvalitet i helsetjenesten etter innføringen av samhandlingsreformen. Dokument 3:5 (2015-2016)

Ruyter K, Førde R, Solbakk JH. Medisinsk og helsefaglig etikk. Oslo, Gyldendal akademisk, 2014.

Schneiderman LJ, Gilmer T, Teetzel HD et al, Effect of ethics consultations on nonbeneficial life-sustaining treatments in the intensive care setting: a randomized controlled trial. JAMA 2003; 290(9):1166-72. http://dx.doi.org/10.1001/jama.290.9.1166

Slowther A, Hope T, Ashcroft R. Clinical ethics committees: a worldwide development. Journal of Medical Ethics. 2001; 27: i1. http://dx.doi.org/10.1136/jme.27.suppl_1.i1

Söderhamn U, Kjøstvedt HT, Slettebø Å. Evaluation of ethical reflections in community healthcare. A mixed-methods study. Nursing Ethics. 2015; Mars 23.1-11

Tønnessen, S., Lillemoen, L., \& Gjerberg, E. (2016). Refleksjonsgrupper i etikk: «Pusterom» eller læringsarena?. Etikk i Praksis - Nordic Journal of Applied Ethics, 10(1), 75-90. http://dx.doi.org/10.5324/eip.v10i1.1844 